\title{
PROSPECTS FOR DIGITALIZATION OF THE ECONOMY OF UKRAINE: OPPORTUNITIES AND THREATS*
}

\author{
Elena Dovgal \\ Doctor of Economic Sciences, Professor \\ Arthur Golikov International Economic Relations Department \\ V.N. Karazin Kharkiv National University \\ Svobody sq., 6, Kharkiv, Ukraine, 61022 \\ e-mail: e.dovgal@karazin.ua \\ ORCID: https://orcid.org/0000-0003-3219-9731 \\ Scopus Author ID: 57217603375 \\ Georgiy Dovgal \\ Candidate of Economic Sciences, Associate Professor \\ Department of Travel Business and Country Studies \\ V.N. Karazin Kharkiv National University \\ Svobody sq., 6, Kharkiv, Ukraine, 61022 \\ e-mail: g.dovgal@karazin.ua \\ ORCID: https://orcid.org/0000-0002-0644-1793 \\ Maria Ishchenko \\ Senior Lecturer \\ Arthur Golikov International Economic Relations Department \\ V.N. Karazin Kharkiv National University \\ Svobody sq., 6, Kharkiv, Ukraine, 61022 \\ E-mail: lazarchuk@karazin.ua \\ ORCID: https://orcid.org/0000-0003-4275-9579
}

\begin{abstract}
Today in some countries there is more and in others - less effective digital transformation in the direction of introduction and use of modern digital technologies in the field of tangible and intangible production. Its goal is to increase the productivity and competitiveness of enterprises, as well as the national economy as a whole. The subject of the article is the process of creation and development of the digital economy. It is he who in the future must bring material production to a new level and ensure the solution of the problems of international competitiveness of domestic production and national security of Ukraine. The aim of the article is to study the prospects of innovative development of Ukraine in the context of digitalization of the economy, as well as related opportunities and threats to the Ukrainian economy. General scientific methods are used, such as systems analysis, synthesis and abstract-logical analysis to study the essence of the digital economy, which creates conditions for efficient production of material goods, determines progress in all areas of the national economy. The following results have been obtained: in the modern sense, the digital economy is an infrastructure of economic activity based on information and computer digital technologies, cyberphysical systems, and artificial intelligence. This process dictates its own rules for the further development of material production, management and regulation, the system of social relations, the legal system and society as a whole. Conclusions: among the main tasks of the national program to create a digital economy in the emerging global digital space, should be highlighted digitization of material production, services and society as a whole, as well as ensuring effective participation of the country in all processes of global ecosystems of the digital economy and the global digital space. Today, Ukraine has a unique opportunity to make a "digital leap" in the main sectors of the economy. The development of digital infrastructure will guarantee new jobs, which will help reduce unemployment. It is the timely transition and massive digitalization that will help Ukraine integrate into the global trend.
\end{abstract}

Keywords: INDUSTRY 4.0, digital economy, global digital space, digital technologies, artificial intelligence, cybersecurity.

Introduction. INDUSTRY 4.0, like previous industrial revolutions, covers material production,

which transforms all aspects of human life: the person himself, his family and family

\footnotetext{
* Cite as: Dovgal, E., Dovgal, G., Ishchenko M. (2021). Prospects for Digitalization of the Economy of Ukraine: Opportunities and Threats, The Journal of V. N. Karazin Kharkiv National University. Series: International Relations. Economics. Country Studies. Tourism. 13, 78-88. https://doi.org/10.26565/2310-9513-2021-13-08 
relationships, social relations, the business environment, the structure of the state and the system of public administration.

In the deployment of INDUSTRY 4.0 and its product, the digital economy, a small group of countries are leading. The world leaders in terms of the contribution of INDUSTRY 4.0 to the country's GDP are Great Britain, the Republic of Korea, China, India, Japan, and the USA [1].

The nature of the manifestation and goals of INDUSTRY 4.0 in different countries is noted and depends on the level of their development and the tasks being solved. So in Germany, the program "Industry 4.0" is being implemented - the focus on the processing industry, in Japan - "Society 5.0" people are at the forefront, in the USA - Digital Economy Agenda - government support for the development of new technologies, in the UK Digital Strategy - a strategy for the development of digital technologies, in China - state projects "Plan 863" (name 863 - dated March 3, 1986), "Torch", Made in China 2025[2].

Today, in some countries there is more, and in others - less effective digital transformation is going on, representing the introduction and use of modern digital technologies in the field of material and non-material production in order to increase the productivity and competitiveness of enterprises/organizations. Digital transformation leads to professional transformation. The success of the digital transformation policy is primarily determined by availability of professional staff, interest and opportunities of the business community, material and financial resources, control system, the political will of the country's leadership [3].

Analysis of recent research and publications. Many scientific works of domestic researchers are devoted to the study of various aspects of the development of the digital economy. In particular, N. Kasianova, O. Kendiukhov, O. Kochubei, Y. Oliinyk, O. Sokhatska, and Yu. Zhukova [4] analyze the state of the domestic IT market and conclude on the need to develop a unified strategy for digital transformation of Ukraine's economy, which should be the goal of cooperation between the state, science and business. V. Zarubei, V. Kuybida, A. Kozhyna, L. Vdovichena, N. Varenia [5] explore the prospects for the development of management of socio-economic security of Ukraine, taking into account the potential of digitalization, as well as the strategy of public administration for the coming years.

Valuable in the scientific sense of research on the problems of the digital economy are scientific works and practical research and development of modern scientists. R. Heeks [6] identifies the strategic priorities of the digitalization policy of the economy in developing countries, gives recommendations on why and what interventions are needed. T. Niebel [7] analyzed the phenomenon of the collision of information and technology, the impact of new means of communication on the processes of economic growth on the example of the European Union over a 15-year period. Z. Zhou, S. Xie, D. Chen [8] considered in detail the methods of digital science of production to solve practical technological problems in modern production processes.

Thus, the issue of digital economy is reflected in numerous studies of economists. However, the high speed of transformation processes taking place in the modern world causes a rapid change in many aspects of the digital economy. Digitization extends to an increasing number of processes and phenomena, which requires appropriate research and determines their relevance.

Thepurpose of the article is to research of prospects of innovative development of Ukraine in the context of digitalization of economy.

Results and discussion. The main goal of the development of the digital economy in the country is the creation and development of a digital environment - infrastructure, which in the future should bring material production to a new level and provide a solution to the problems of international competitiveness of domestic production and the national security of Ukraine. And the overriding goal is to improve the quality of life. There is a direct relationship between the formation of a digital economy in the country and an increase in the welfare of the population: without an increase in welfare, it is difficult to achieve a real formation of the digital economy, and without it, an increase in welfare becomes virtually fabulous [9].

In the modern sense, the digital economy is an infrastructure of economic activity based on information and computer digital technologies, cyber-physical systems (CPS), artificial intelligence (AI), which dictate their own rules for the further development of material and non-material production, management and regulation systems, systems of social relations, the legal system and society as a whole. The national program for creating a digital economy should cover the service sector and, above all, the public service sector, the state management system and provide for:

creation of a supporting infrastructure for the digital economy;

- cardinal improvement of the education system;

- ensuring universal digital literacy;

- support for domestic companies generators of digital and other end-to-end technologies [10].

In reality, this is the path that developed countries have already passed or are completing. Ukraine lingered on this path. Therefore, among the main tasks of the national program for creating a digital economy within the framework of the emerging global digital space, one should highlight: 
- $\quad$ providing technological leadership;

formation of a qualitatively new structure of economic assets;

digitalization of the branches of material production, the service sector and in general the entire socio-economic, state and public life of society;

formation of the principles of digital management of economic resources;

building confidence in the digital economy and the digital environment among the domestic business community and civilian population through the attractiveness of organizational and regulatory mechanisms and the work of state bodies, in particular structures such as multifunctional centers;

- $\quad$ improving the well-being of the population;

- ensuring the security and sovereignty of the national space of the digital economy;

ensuring effective participation of the country in all processes of the formation of the global ecosystem of the digital economy and the global digital space, which, in particular, provides for the creation of smart cities based on information and communication technologies (ICT) aimed at reducing the level of bureaucracy and the transition of state bodies to digital media instead of paper [4].

The digital economy in all formats does not by itself produce food, clothing, equipment, motor fuel, etc., but creates conditions for the efficient production of material goods, predetermines progress in all spheres of the national economy. In Ukraine, for this it is necessary to carry out the following measures:

end-to-end automation of all major production and economic processes;

- development of the market for personalized production and consumption;

- increasing the aggregate efficiency of economic entities;

exchange; mobilization of knowledge through creation of new jobs in high-tech industries;

- creation of conditions for the development of entrepreneurial and labor activity;

- $\quad$ creating conditions for improving the level and quality of life of the population; ensuring technological leadership in the global digital space; development of the processing industry based on artificial intelligence; introduction of effective forms of management; full development of small, medium and individual entrepreneurship; the formation of a digital space and the trust of entrepreneurship and the population in the digital environment; guaranteeing the security and sovereignty of the domestic digital economy space; ensuring effective participation of the state, the domestic business community and civil society in the processes of forming a global ecosystem of the digital economy and the global digital space [5].

All of the above is the sunny side of the promoted digital economy, behind which its shadow underpinnings are hidden. Knowledge and understanding of the hidden side of the digital economy allows you to take preventive measures to neutralize and eliminate negative consequences.

Humanity is on the verge of an allencompassing crisis (spiritual, cultural, environmental, political, economic) and is not ready to accept the digital economy in full scale and in full due to its moral and ethical imperfection. Under certain conditions, the products of the digital economy can negatively affect the functionality and work skills of a person: worsen his memory (why remember if there are smartphones);

suppress his skills of spatial and geographical orientation, making a person dependent on navigators built into smartphones and tablets, and in the near future, into the person himself;

- $\quad$ reduce the ability to manual labor;

- $\quad$ to kill the ability to express one's thoughts clearly, clearly, beautifully, since the memory, which is replaced by gadgets, works poorly, and in the near future artificial intelligence will write everything for a person, express his thoughts, ideas;

to replace analytical thinking with clip consciousness [5].

Among the factors holding back and even blocking the development of the digital economy in Ukraine, one should single out socio-economic, legal and political factors, as well as national characteristics. All of these factors are interrelated. Each of them affects all the others, ignoring one factor negatively affects all the others.

The social factor, first of all, should be attributed to low wages. The underestimated wages of the working population blocks the formation and development of a solvent consumer market, effective demand and sales markets for products of both traditional (analog) and digital economies. As a result, the life of some families does not even fit into the system of existence from paycheck to paycheck, while others are abundant. Unfortunately, the former constitute the critical mass, which determines the socio-economic situation in the country. Low salaries and a low standard of living not only prevent the consumer market from developing, but also reduce the motivation to increase the efficiency of labor activity, and, therefore, to implement and use the achievements of the digital economy [5].

An undeveloped consumer market hinders the development of entrepreneurial activity. 
Ultimately, the growth of the social divide and the gap between capital and labor incomes widens and, as a result, inequality increases. The problems of poverty and social stratification are worldwide. As shown by a study by the international organization Oxfam dealing with poverty issues and the Swiss bank Credit Suisse, about $82 \%$ of all benefits created in the world in 2019 are concentrated in the hands of only $1 \%$ of the world's population, which is far from the most talented [11].

The success of creating a digital economy is determined not only by financing, reducing corruption, theft and fraud, but also largely by the awareness and understanding of the population and entrepreneurs of its essence, its importance for everyone. The person (population) who will directly implement the digital economy expects certain advantages and benefits from its implementation. A person should feel its necessity, advantages and benefits that it brings, relief in solving everyday problems, feel a real growth in their well-being, an increase in free time and the possibility of a normal rest [9].

Support for small and medium-sized businesses can become a real force in the development of the digital economy. What is difficult to establish at large enterprises can today be performed by small and medium-sized businesses, as well as individual entrepreneurs and inventors, i.e. people organizing a unique production. Entrepreneurs need a sales market, they need a solvent consumer who wants and can buy their products. We are talking about the final consumer of digital economy products. Small and medium businesses are potential taxpayers.

The coincidence of interests of the population, business and the state is the most important basis for the implementation of any program. Businesses are showing interest in the implementation of innovative projects and the digital economy. State support is required: financial, administrative, legal. In the USA, Germany, China, and Great Britain, businesses receive broad support in the development of the digital economy [3].

Import dependence has become the Achilles heel of the Ukrainian economy, which manifested itself in the country's growing dependence on imports of hydrocarbons and all industrial and consumer (non-food) goods, which means complete dependence on world prices for hydrocarbons [3].

The dependence on imports of industrial equipment in the current environment is becoming a brake on the development of the digital economy in Ukraine. Today, the domestic industry operates mainly on imported equipment and foreign technologies, which are supposed to be digitized and robotized within the digital economy. This direction of development of the Ukrainian economy puts it under foreign control. According to J'son \&
Partners Consulting experts, the leaders in the production of electronic and optical equipment are China, Japan, the Republic of Korea, with the USA, Germany, France, Great Britain and Italy behind them. In the future, Ukraine's ability to approach developed countries in terms of production of such important equipment necessary for the implementation of the digital economy looks very doubtful [3].

Today, the national mentality does not correspond to the ongoing rapid changes, it is characterized by subjectivity in decision-making. This blocks work with big data (DB), from which it is necessary to correctly select the necessary information of the required volume to objectively justify decisions. It should be remembered that the Pareto rule works: the accuracy and correctness of processing $20 \%$ of the data allows you to get answers to $80 \%$ of the problems and make the appropriate decisions. The cost of adjusting for minor socioeconomic and / or technical negligence at the start increases with distance from the starting point. In practice, this leads to irretrievable losses of human, material, financial and time resources allocated for the implementation of the decision. And most importantly, the performers have disappointment and distrust in the management system and doubts about the competence of managers. Errors made at the input multiply at the output and turn into an ineffective decision. Database technologies are the speed of finding the right solution from the set, but not the final one. The search and analysis of information with the subsequent choice of strategy and decision-making takes at least 30$35 \%$ of the manager's working time [12].

Any program requires funding and it is no secret that digitalization is very expensive. Given the ineffectiveness of spending funds and invincible corruption, its price will become an unbearable burden for society and, above all, for the population. In addition, one should take into account the impoverishment of the population caused by both external and internal factors, including the dependence of domestic consumer markets (with the exception of food) on imported products. Therefore, it is necessary to attract private capital, creating comfortable conditions for investors.

Monopolization of information flows - a form of modern capital - by a small group (elite), as well as the monopolization of the world's material wealth by this same group, multiplies the stratification of the population. Monopolization of information flows, intensified by the increasing robotization of production and social processes, acts, in fact, to control and monopolize income, enhancing the differentiation of society. Even the spread of broadband Internet will not deprive the elite of the opportunity to maintain monopolization and control over information flows. One must be able to work with information and be able to use 
it. Consequently, differentiation in society will not only persist, but, possibly, increase. A wealthy segment of the population has great opportunity to work with increasing amounts of information and use the results to obtain benefits. This trend manifests itself well at the global level. The information gap, the ability and ability to work with the database between rich and poor countries has a steady upward trend. 2002-2007 the gap between rich and poor countries in the ability to work with huge flows of information has grown from 8 to 15 times [11].

The value of information as capital is constantly increasing. The whole world knows the famous expression of Nathan Rothschild, said by him 200 years ago: who owns information, he owns the world. This is not enough today. You need to be able to structure this information, translate it into knowledge, in competence - the ability to apply the knowledge gained in practice and then into benefits and income.

The personnel issue is a major problem for all countries. The struggle for human capital is escalating, and the value of human capital is constantly increasing. The personnel issue includes the problem of personality and team building, the problem of unique specialists, legislation and professional development. Human resources are the most valuable capital in any country, in any organization or company. The loss of a specialist is irreparable. The no-one is irreplaceable principle is becoming obsolete. There are specialists who have the abilities of an organizer, administrator, generator of ideas, charisma and the ability to select and build a team.

The success of the implementation of the program largely depends on the specific persons who are appointed responsible for the implementation of specific areas of the program.

Team building is another staffing problem. Formation of a team on the principle of nepotism, favoritism, personal loyalty turns into the selection of an incompetent team, incompetent leadership, which ultimately leads to increased corruption, theft, and the collapse of any undertaking. If the selection of personnel is based on the knowledge, competencies, abilities of the individual and her ability to work in a team, success will not be long in coming. It should be recalled that the creation of the digital economy is accompanied by huge financial flows. The latter determines the struggle for participation in the team.

Professional development is another domestic problem. The entrepreneur's investments in education, training and retraining of personnel are designated as production costs. But this is an investment in human capital that allows you to increase production, improve the efficiency of the work process and improve product quality. This investment should pay off [13].

Robotization, drones and deserted production create new professions, but massively displace people, close jobs and do not create new ones. The growing mega-unemployment can become the most difficult problem of digital economy. Rising unemployment could also generate new global labor migration flows. These trends are already evident today. Unemployment as one of the negative properties of any technical and technological progress can give rise to various forms of protest under current conditions. In Great Britain at the beginning of the 19th century. Luddism was born - a protest movement against the mechanization of production during the industrial revolution. Modified forms of this protest may appear today. For example, against robotization.

Massive robotization of production processes and the introduction of smart factories (advocated by the entrepreneurial community), as noted, lead to job losses and the death of many professions. The growth of an army of people deprived of work and means of livelihood intensifies stratification and increases social tension in society, which inevitably leads to riots and revolutionary upheavals. At the same time, companies are losing consumer markets, and with them profits. The production of goods and services becomes meaningless. Many see the way out of the socioeconomic catastrophe in the formation of an unconditional basic income (UBI). This idea is actively supported by American and European entrepreneurs. In the European Union, the minimum tax-free UBI is set at about $€ 1,000$ per person per month from birth to old age. It is assumed that the UBI must guarantee a person freedom from labor slavery. However, according to experts, the estimated size of the UBI will only worsen the financial situation of the poor. UBI, solving a social problem, generates the problem of financing, more precisely, its sources, and contributes to the degradation of the resources of a quality workforce [14].

Digitalization, robotization make a person dependent on technology, smart gadgets, without which it becomes more and more difficult to do without. And this dependence is growing with the increase in the number of smart devices. Memory and knowledge replace smartphones, computers, and the Internet. A person loses the ability to express their thoughts and feelings. Fantasy is replaced by ready-made pictures, curiosity and knowledge - by the Internet. A person strives to get everything at once and quickly without due effort and effort and is not ready to patiently achieve the goal. Technology has always helped a person to survive, and today it determines a person's life. A modern person can no longer do without a smartphone, tablet, navigator, which have become not only a part of his life, but also a part of the person himself. Culture has always been a part of a person's life, determined his development, humanity grew up on culture. The digital economy turns everything upside down: technology 
determines human behavior, his actions, and it is unlikely that culture will help survival in these conditions [15].

The use of foreign search engines and software is a disregard for national security issues. It is enough to analyze the work of the Google search engine, which determines what you are looking for, who is searching, where the search is being conducted, the duration of the search (time spent on the site). Having determined this, the system selects the appropriate material on the next visit. The information from this search engine can be used by the relevant authorities. The use of foreign software puts national security under foreign control.

Outdated and outdated laws and regulations impede the development of the digital economy. By now, too many legislative taboos have accumulated that impede and block the development of entrepreneurial activity. The formation and development of the digital economy requires the creation of a favorable organizational, infrastructural and regulatory framework. We need a national digital jurisdiction for the development of entrepreneurship in a new economic order. The latter puts forward special requirements for legislators. Of these requirements, the need for professionalism and large-scale thinking should be emphasized, including:

availability of knowledge, skills and abilities to timely see trends in the development of business and economy, including digital; ability to predict these trends for the future, for the long term;

the ability to comprehensively and qualitatively analyze the draft law in order to avoid further revisions and amendments;

ability to respond quickly to changes in the socio-economic and political spheres [16].

Bureaucratization and excessive demands on entrepreneurs is another disease of our society, manifested in excessive reporting, endless approvals and lengthy bureaucratic procedures. In Ukraine, document circulation is carried out mainly in paper form, in the USA - in electronic format.

Redundant reporting persists due to the lack of a shared digital trust environment. As a result, the use of the system of electronic contracts is blocked due to the underdevelopment of the use of digital signatures and the system of identification and authentication of persons. Until now, the oldest system of confirmation of the authority of some persons in relation to other persons and organizations operates on the basis of a paper system of notarial powers of attorney. Creating a unified digital environment of trust will reduce costs and accelerate the formation of new business processes. A comprehensive legislation on the digital economy is required, focused on the longterm perspective of the development of the virtual and real economies, as well as providing for the elimination of legislative barriers. In particular, it is necessary to resolve the issues of legislative regulation of the technology of using big data and blockchain technology. To date, the use of these technologies in companies and government bodies is not legally defined. Business entities must be sure that they do not violate the law using new technologies.

The process of adopting regulatory legal acts has a very long way to go, which does not correspond to constantly accelerating changes in reality, and even more so will not correspond to changes in the digital economy. Control system. The existing system of management and regulation, enveloped in a network of corruption, does not ensure effective development, on the contrary, it hinders it. The state management and control system significantly lags behind the development of the digital economy and its components in other countries, including the information flows of big data and the development of digitalization. The regulatory environment of the digital economy must quickly change to meet the changing reality.

The digital economy, like any phenomenon, has two sides, and they must be compared, commensurate. An analysis of the explicit and hidden side of the digital economy makes it possible to work out measures to strengthen and develop its positive prospects, but at the same time to develop a program to neutralize its negative properties. Historically, two polar approaches to the assessment of technical and technological progress have developed: technical optimism (technophilia) and technical pessimism (technophobia). Technophilia absolutes positive prospects for the development of technology and technology. This is what is happening around the world today in connection with the prospect of realizing the digital economy. Technophobia reflects the fear of scientific and technological progress generated by its negative sides - weapons of mass destruction (nuclear weapons, cruise missiles, drones), environmental pollution, etc.

It is necessary to take both sides into account when developing practical steps to create a digital economy. It is unconditional that the creation of a digital economy brings with it negative consequences and risks, which are already clearly visible today. Robotization improves the quality of products, excluding the human factor, but at the same time there is a danger of failure, hacker attack, virus. The psychological problems of digital transformation are associated with the transition from the virtual world to the real one and vice versa. The danger is the return from the fabulous, beautiful and harmonious virtual world, in which everything is fine and sunny for a person, to the real world, in which a person is faced with many unsolvable problems, the lawlessness of an official, injustice, instability, etc. The new world 
based on digital technologies changes the personality of a person, lays new principles in ethics, morality and the system of values. With the development of digitalization - the digitization of the human environment - the individual behavior of a person will be digitized, which will change his psyche. Digitizing behavior can trigger a split personality. As a result, the following can occur: alienation of a person from his inner world, deformation of a person's personality, narrowing of the freedom to form his own personality, segregation of people - discrimination of certain social groups and ethnic groups based on their identity, which can result in the polarization of human communities.

The widespread introduction of digital technologies into social and economic life gives rise to the problem of preserving the moral and ethical values of a person, his readiness to accept these changes and adapt to them. Already today, society is faced with the problem of manipulating the subconscious of a person by individuals, individual groups and the authorities. The increasing interweaving of the physical world with the digital one gives the power, a small hierarchically structured group of people, the ability to monitor, control and channel the behavior of the masses. The reverse process is also possible. New technologies give people, civil society the opportunity to influence the political life of the state.

In this sense, ensuring information and economic security is a prerequisite for creating a digital economy that needs protection from hacker attacks, hacks and viruses. The digitization of the entire system of human life and society generates, simultaneously with progress, the following consequences: an increase in unemployment, further polarization of society and increased inequality, cyber security problems, Internet fraud, the introduction of viruses, an increase in hacking, a new round of cybercrime, terrorism and organized crime.

In addition, the development of the digital economy carries such threats in certain industries and fields of activity. For example, in the industry of organizational group tourism - in the form of further development of independent travel organization based on on-line platforms; auto insurance - due to the further spread of the use of self-driving cars; financial consulting - through the introduction of robotic consultants; the system of service and repair of diesel and gasoline vehicles, which are replacing electric vehicles.

The digital economy is a powerful instrument of power that, together with private ownership of digital technologies, can be used up to the establishment of a dictatorship. Therefore, the main directions of strengthening cybersecurity in the process of creating a digital economy, in our opinion, are the installation of domestic anti-virus programs and the ousting of foreign hardware and software and the use of domestic hardware and software.

The digital economy is fundamentally changing the nature of crime and terrorism, giving rise to new threats on a global scale, allowing you to attack objects remotely from anywhere in the world. The scale of computer crime in the banking and financial sphere and in the area of violation of constitutional human and civil rights and freedoms, including inviolability of private life, personal and family secrets, is growing significantly. In addition, private information is hacked (unauthorized penetration into it), the scale and number of coordinated computer attacks on financial, economic and military strategic facilities are growing.

Such unlawful actions can be resisted only by the combined efforts of all countries, by creating a global security architecture, including the introduction of uniform methods and rules for combating cybercrime, developing partnerships, maintaining constant contacts and cooperation.

Digital technologies make national economies vulnerable both from hackers and from transnational corporations and states. There is a possibility of hostile information and technical impact on the infrastructure of the economy for political, economic and military purposes. Recently, the activity of technical intelligence and special services of individual states in the field of information and psychological impact on the destabilization of the financial and economic situation in various regions of the world has been increasing, which violates the sovereignty and territorial integrity of other states.

In this regard, ensuring information security in Ukraine requires: to treat the domestic labor resources with care; create better living conditions for programmers in comparison with foreign ones; develop and implement effective competitive electronic technologies; pay attention to the problem of staffing (training people on the use of digital technologies); engage in the organization of permanent scientific research that contributes to the creation of promising digital technologies; solve the problems of ensuring cryptographic (digital) sovereignty; ensure the development of digital information infrastructure.

From the point of view of national interests, information security in the process of creating a digital economy involves:

innovative development of the electronic industry and information technology;

elimination of the dependence of the domestic economy on foreign information technologies and information security means; creation, development and mass introduction of domestic developments; - provision of services based on domestic developments; creating competitive advantages for domestic companies: a) in the field of information technology and electronic industry, b) in the 
development, production and operation of information security tools;

development of a domestic progressive electronic component base and production of electronic components to meet the demand of the domestic market with access to the world market.

And finally, ensuring information security in the field of science, technology and education needs:

- in financing the basic sciences;

- freedom of scientific creativity without censorship and other restrictions;

development of scientific and technical potential in the field of information security; creation and implementation of effective and resistant to external influences of information technologies.

Conclusion. Thus, the transition to digital format is a challenge not only for all sectors of the economy, not only in Ukraine but also around the world. Digital conversions are a challenge. Countries that have reached the highest level of digital maturity have had to deal with complex cultural, organizational, and technical challenges, and only taking all these factors into account has made these transformations successful. In order to become digital leaders in specific areas of the economy today, it is necessary to identify priority digital projects that are implemented by specific organizational teams. As for Ukraine, given the current state of the economy, global development trends, the availability of human potential and resources, as well as fundamental changes in the international labor market, we can conclude that today the priority path of development should be the transition of all sectors of the Ukrainian economy to digital format. with an emphasis on maximum investment in the development of digital infrastructures, innovations and modern technologies. Today, Ukraine has a unique opportunity to make a "digital leap" in the main sectors of the economy. The development of digital infrastructure will guarantee new jobs, which will help reduce unemployment. Timely transition and mass digitalization will help to integrate into the global trend. Otherwise, there is a threat of remaining on the sidelines of global development.

\section{ПЕРСПЕКТИВИ ЦИФРОВІЗАЦІї ЕКОНОМІКИ УКРАЇНИ: МОЖАИВОСТІ ТА ЗАГРОЗИ}

Довгаль Олена Андріївна,доктор економічних наук, професор, професор кафедри міжнародних економічних відносин імені Артура Голікова Харківського національного університету ім. В. Н. Каразіна, майданСвободи, 4, м. Харків, 61022, Україна, E-mail: e.dovgal@karazin.ua, ORCID: https://orcid.org/0000-0003-3219-9731, ScopusAuthorID: 57217603375.

Довгамь Георгій Вомодимирович,кандидат економічних наук, доцент, доцент кафедри туристичного бізнесу та країнознавства Харківського національного університету ім. В.Н. Каразіна, майданСвободи, 4, м. Харків, 61022, Україна, E-mail:g.dovgal@karazin.ua, ORCID: 0000-0002-06441793.

Іщенко Марія Охександрівна,старший викладач кафедри міжнародних економічних відносин імені Артура Голікова Харківського національного університету ім. В.Н. Каразіна, майданСвободи, 4, м. Харків, 61022, Україна, E-mail:lazarchuk@karazin.ua

Сьогодні в одних країнах відбувається більше, а в інших - менш ефективна цифрова трансформація в напрямку впровадження та використання сучасних цифрових технологій у галузі матеріального та нематеріального виробництва. ІІї метою $є$ підвищення продуктивності та конкурентоспроможності підприємств, а також національної економіки в цілому. Предметом дослідження статті є процес створення та розвитку цифрової економіки. Саме він у майбутньому повинен вивести матеріальне виробництво на новий рівень та забезпечити вирішення проблем міжнародної конкурентоспроможності вітчизняного виробництва та національної безпеки України. Метою статті $є$ дослідження перспективи інноваційного розвитку України в контексті цифровізації економіки, а також пов язані з цим можливості та загрози для української економіки. Застосовуються загальнонаукові методи, такі як системний аналіз, синтез та абстрактно-логічний аналіз для дослідження сутності цифрової економіки, що створює умови для ефективного виробництва матеріальних благ, зумовлює прогрес у всіх сферах національної економіки. Отримані наступні результати: у сучасному розумінні цифрова економіка - це інфраструктура господарської діяльності, заснована на інформаційних та комп’ютерних цифрових технологіях, кіберфізичних системах, штучному інтелекті. Це процес диктує власні правила подальшого розвитку матеріального виробництва, управління та регулювання, системи суспільних відносин, правової системи та суспільства в цілому. Висновки: серед основних завдань національної програми створення цифрової економіки в рамках світового цифрового простору, що формується, слід виділити цифровізацію галузей матеріального виробництва, сфери послуг та загалом усього соціально-економічного та суспільного життя суспільства, а також забезпечення ефективної участі країни в усіх процесах формування глобальної екосистеми цифрової економіки та глобального цифрового простору. Саме сьогодні Україна має унікальну можливість зробити "цифровий стрибок" у головних сферах економіки. Розвиток цифрової інфраструктури гарантуватиме нові робочі місця, що сприятиме зниженню безробіття. Саме своєчасний перехід і масова діджіталізація допоможуть Україні інтегруватися в загальносвітовий тренд. 
Кмючові слова: промисловість 4.0, цифрова економіка, глобальний цифровий простір, цифрові технології, штучний інтелект, кібербезпека.

\section{ПЕРСПЕКТИВЫ ЦИФРОВИЗАЦИИ ЭКОНОМИКИ УКРАИНЫ: ВОЗМОЖНОСТИ И УГРОЗЫ}

Довгамь Елена Андреевна, доктор экономических наук, профессор, профессор кафедры международных экономических отношений имени Артура Голикова Харьковского национального университета имени В. Н. Каразина, пл. Свободы, 4, г. Харьков, 61022, Украина, e-mail:e.dovgal@karazin.ua, ORCID: https://orcid.org/0000-0003-3219-9731, ScopusAuthorID: 57217603375.

Довгамь Георгий Вмадимирович, кандидат экономических наук, доцент, доцент кафедры туристического бизнеса и страноведения Харьковского национального университета имени В. Н. Каразина, пл. Свободы, 4, г. Харьков, 61022, Украина; e-mail:g.dovgal@karazin.ua, ORCID: 0000-0002-0644-1793.

Ищенко Мария Амександровна, старший преподаватель кафедры международных экономических отношений имени Артура Голикова Харьковского национального университета имени В. Н. Каразина, пц. Свободы, 4, г. Харьков, 61022, Украина, E-mail: lazarchuk@karazin.ua

Сегодня в одних странах происходит более, а в других - менее эффективная цифровая трансформация в направцении внедрения и использования современных цифровых технологий в области материального и нематериального производства. Ее целью является повышение производительности и конкурентоспособности предприятий, а также национальной экономики в целом. Предметом исследования статьи является процесс создания и развития цифровой экономики. Именно он в будущем должен вывести материальное производство на новый уровень и обеспечить решение проблем международной конкурентоспособности отечественного производства и национальной безопасности Украины. Целью статьи является исследование перспективы инновационного развития Украины в контексте цифровизации экономики, а также связанные с этим возможности и угрозы для украинской экономики. Применяются общенаучные методы, такие как системный анализ, синтез и абстрактно-логический анализ дмя исследования сущности цифровой экономики, которая создает условия для эффективного производства материальных благ, предопределяет прогресс во всех сферах национальной экономики. Получены следующие результаты: в современном понимании цифровая экономика - это инфраструктура хозяйственной деятельности, основанная на информационных и компьютерных цифровых технологиях, киберфизичних системах, искусственном интемлекте. Этот процесс диктует свои правима дальнейшего развития материального производства, управления и регулирования, системы общественных отношений, правовой системы и общества в целом. Выводы: среди основных задач национальной программы создания цифровой экономики в рамках формирующегося мирового цифрового пространства следует выделить цифровизацию отраслей материального производства, сферы услуг и в целом всей социально-экономической и общественной жизни общества, а также обеспечение эффективного участия страны во всех процессах формирования глобальной экосистемы цифровой экономики и глобального цифрового пространства. Именно сегодня Украина имеет уникальную возможность сделать "цифровой скачок" в основных сферах экономики. Развитие цифровой инфраструктуры будет гарантировать новые рабочие места, способствовать снижению безработицы. Именно своевременный переход и массовая диджитализация помогут Украине интегрироваться в общемировой тренд.

Кмючевые слова: промышленность 4.0, цифровая экономика, глобальное цифровое пространство, цифровые технологии, искусственный интемлект, кибербезопасность.

\section{Мiтература}

1. Рейтинг инновационных экономик - 2019: Южная Корея мидирует шесть мет. URL: https://theworldonly.org/rejting-innovatsionnyh-ekonomik-2019/.

2. Ц Цифрова економіка: тренди, ризики та соціальні детермінанти. Центр Разумкова, 2020. URL: https://razumkov.org.ua/uploads/article/2020_digitalization.pdf

3. Dovgal O., Dovgal G. Industry 4.0: new opportunities and new challenges. Theory, science and practice. Abstracts of III International Scientific and Practical Conference.Tokyo, Japan 2020. Pp. 13-16. DOI: 10.46299/ISG.2020.II.III. URL: https://isg-konf.com/uk/theory-science-and-practice-ua/

4. Kasianova N., Kendiukhov O., Kochubei O., Oliinyk Y., Sokhatska O., Zhukova Yu., Digital Transformation as an Attractor of Ukraine's Economic Development, International Journal of Advanced Research in Engineering and Technology, 11(7), 2020, pp. 340-349. https://doi.org/ 10.34218/IJARET.11.7.2020.034 
5. Zarubei V., Kuybida V., Kozhyna A., Vdovichena L., Varenia N., Modeling and Technology of Public Administration of Socio-Economic Security for Digitalization, International Journal of Management (IJM), 11 (3), 2020, pp. 143-154. https://doi.org/10.34218/IJM.11.3.2020.016

6. Heeks R. Digital Economy Policy Strategy Brief. Centre for Development Informatics Global Development Institute, SEED University of Manchester, Arthur Lewis Building, Manchester, 2018 , M13 9PL, UK. https://doi.org/10.13140/RG.2.2.11124.09602.

7. Niebel T. ICT and Economic Growth: Comparing Developing, Emerging and Developed Countries. World Development, Volume 104, April 2018, Pp. 197-211. https://doi.org/10.1016/j.worlddev.2017.11.024

8. Zhou Z., Xie S., Chen D. Fundamentals of Digital Manufacturing Science. London: SpringerVerlag London Limited. 2017. https://doi.org/10.1007/978-0-85729-564-4

9. Dovgal O., Makhova L. Development of the theory of innovations in the context of the new industrial revolution. Вісник ХНУ імені В.Н. Каразіна, серія "Міжнародні відносини. Економіка. Країнознавство. Туризж. 2020. № 11. С .62-68. https://doi.org/10.26565/2310H9513H2020H11H07

10. Schwab K. The Fourth Industrial Revolution. What It Means and How to Respond. Foreign Affairs, 12 Dec 2015. URL: https://www.foreignaffairs.com/articles/2015-12-12/fourth-industrialrevolution.

11. Statistics. Official site of the International union of telecommunication (MSE, English International Telecommunication Union, ITU). URL: https://www.itu.int/en/ITUD/Statistics/Pages/stat/default.aspx

12. Розвиток електронних послуг. Урядовий портал: веб-сайт. URL: https://www.kmu.gov.ua/ua/diyalnist/reformi/efektivne-vryaduvannya/rozvitok-elektronnih-poslug.

13. Цифрова економіка України: час діяти настав. URL: https://issuu.com/mineconomdev/docs/.

14. Exploring Universal Basic Income : A Guide to Navigating Concepts, Evidence, and Practices, The World Bank. February 4, 2020. https://www.worldbank.org/en/topic/socialprotection/publication/exploring-universal-basic-incomea-guide-to-navigating-concepts-evidence-and-practices.

15. Measuring the Digital Economy. The 5th IMF Statistical Forum Session II: Framing the Conceptual Issue Discussion by Vitor Gaspar, Director, Fiscal Affairs Department, IMF. International Monetary Fund, 16 Nov 2017. URL: https://www.imf.org/en/News/Articles/2017/11/16/sp111617measuring-the-digital-economy.

16. Розпорядження Кабінету Міністрів України «Про схвалення Концепції розвитку цифрової економіки та суспільства України на 2018-2020 роки та затвердження плану заходів щодо iï реалізації.. Урядовий портал: веб-сайт. 17.01.2018. URL: https://www.kmu.gov.ua/ua/npas/proshvalennya-koncepciyi-rozvitku-cifrovoyi-ekonomiki-ta-suspilstva-ukrayini-na-20182020-roki-tazatverdzhennya-planu-zahodiv-shodo-yiyi-realizaciyi.

\section{References}

1. Rejtyng innovacyonnyh ekonomik - 2019: Juzhnaja Koreja ledyruet shestj let [Innovation Economy Ranking 2019: South Korea leads six years]. URL: https://theworldonly.org/rejtinginnovatsionnyh-ekonomik-2019/.

2. Cyfrova ekonomika: trendy, ryzyky ta sotsialni determinanty. (2020). Tsentr Razumkova. [Digital economy: trends, risks and social determinants].URL: https://razumkov.org.ua/uploads/article/2020_digitalization.pdf

3. Dovgal O., Dovgal G. (2020). Industry4.0: new opportunities and new challenges. Theory, science and practice. Abstracts of III International Scientific and Practical Conference.Tokyo, Japan. Pp. 13-16. URL: https: / /isg-konf.com/uk/theory-science-and-practice-ua/

4. Kasianova N., Kendiukhov O., Kochubei O., Oliinyk Y., Sokhatska O., Zhukova Yu. (2020) / Digital Transformation as an Attractor of Ukraine's Economic Development, International Journal of Advanced Research in Engineering and Technology, 11(7), pp. 340-349. https://doi.org/10.34218/IJARET.11.7.2020.034

5. Zarubei V., Kuybida V., Kozhyna A., Vdovichena L., Varenia N. (2020). Modeling and Technology of Public Administration of Socio-Economic Security for Digitalization, International Journal of Management (IJM), 11 (3), pp. 143-154. https://doi.org/ 10.34218/IJM.11.3.2020.016

6. Heeks R. (2018). Digital Economy Policy Strategy Brief. Centre for Development Informatics Global Development Institute, SEED University of Manchester, Arthur Lewis Building, Manchester, M13 9PL, UK. https://doi.org/10.13140/RG.2.2.11124.09602 
7. Niebel T. (2018). ICT and Economic Growth: Comparing Developing, Emerging and Developed Countries. World Development, Volume 104, April 2018, Pages $197-211$. https://doi.org/10.1016/j.worlddev.2017.11.024

8. Zhou Z., Xie S., Chen D. (2017). Fundamentals of Digital Manufacturing Science. London: Springer-Verlag London Limited. https://doi.org/10.1007/978-0-85729-564-4

9. Dovgal O., Makhova L. (2020).Development of the theory of innovations in the context of the new industrial revolution. Visnyk KhNUimeni V.N. Karazina, seriia "Mizhnarodni vidnosyny. Ekonomika. Krainoznavstvo. Turyzm». № 11. C .62-68. [The Journal of V. N. KarazinKharkiv National University. Series "International Relations. Economics. Country Studies. Tourism"]. https://doi.org/10.26565/2310H9513H2020H11H07/

10. Schwab K. (2015). The Fourth Industrial Revolution. What It Means and How to Respond. Foreign Affairs. URL: https: / /www.foreignaffairs.com/articles/2015-12-12/fourth-industrial-revolution.

11. Statistics. Official site of the International union of telecommunication (MSE, English International Telecommunication Union, ITU). URL: https://www.itu.int/en/ITUD/Statistics/Pages/stat/default.aspx

12. Rozvytok elektronnyh posluh [Development of electronic services]. Urjadovyj portal. URL: https://www.kmu.gov.ua/ua/diyalnist/reformi/efektivne-vryaduvannya/rozvitok-elektronnih-poslug.

13. Cyfrova ekonomika Ukrajiny: chas dijaty nastav [Digital economy of Ukraine: time to act has come]. URL: https://issuu.com/mineconomdev/docs/.

14. Exploring Universal Basic Income : A Guide to Navigating Concepts, Evidence, and Practices, The World Bank. February 4, 2020. https://www.worldbank.org/en/topic/socialprotection/publication/exploring-universal-basic-incomea-guide-to-navigating-concepts-evidence-and-practices.

15. Measuring the Digital Economy. The 5th IMF Statistical Forum Session II: Framing the Conceptual Issue Discussion by Vitor Gaspar, Director, Fiscal Affairs Department, IMF. International Monetary Fund, 16 Nov 2017. URL: https://www.imf.org/en/News/Articles/2017/11/16/sp111617measuring-the-digital-economy.

16. Rozporjadzhennja Kabinetu Ministriv Ukrajiny «Pro skhvalennja Koncepciji rozvytku cyfrovoji ekonomiky ta suspiljstva Ukrajiny na 2018-2020 roky ta zatverdzhennja planu zakhodiv shhodo jiji realizaciji" [Order of the Cabinet of Ministers of Ukraine "On Approval of the Concept for the Development of the Digital Economy and Society of Ukraine for 2018-2020 and Approval of the Action Plan for its Implementation"]. Urjadovyj portal: website. 17.01.2018. URL: https://www.kmu.gov.ua/ua/npas/pro-shvalennya-koncepciyi-rozvitku-cifrovoyi-ekonomiki-tasuspilstva-ukrayini-na-20182020-roki-ta-zatverdzhennya-pla-nu-zahodiv-shodo-yiyi-realizaciyi.

Статтю отримано 28 квітня 2021 р. 